\title{
Impact of Fires and Grazing Closure on Rehabilitation of Gregariously Flowered Bamboo (Dendrocalamus strictus (Roxb) Nees) Forests
}

\author{
O.P. Chaubey, Archana Sharma and Ram Prakash \\ State Forest Research Institute, Jabalpur - 482008 (M.P.) \\ chaubey.dr@gmail.com,archanasharma.sharma6@gmail.com,sdfri@rediffmail.com
}

\begin{abstract}
After gregarious flowering, the natural regeneration of Dendrocalamus strictus (Roxb.) Nees forms carpet on forest floor and remained in whippy stage for several decades in face of severe biotic factors. The present paper deals with the impact of different treatments of fire and grazing closures for rehabilitation of natural regeneration. The treatments were given after formation of bamboo elites. The findings revealed that lit of fire in the month of May proved better in terms of culms growth and clump formation, followed by fire in the month of March. Two fire in a year i.e., fire in March and May, showed detrimental effect on culms growth and clump formation. Similarly, in the experiment of different periods of grazing closures, complete closure for five years proved significantly effective to stimulate growth of bamboo seedlings. This was followed by six months grazing closure (from July to December), and three months (July to Sept.) grazing closure in a year.
\end{abstract}

Keywords: Natural regeneration, rehabilitation, fire, grazing closure, greagarious flowering

\section{Introduction}

Bamboo is of vital importance from ecological, commercial and socio-economic points of view. Bamboo occupies an unparalleled position in plant kingdom in terms of its distribution, diversity, flowering and uses in the tropics and subtropics (Rai and Chauhan, 1998; Rawat and Kahduri, 1999; Ansari et al., 2002). Bamboo is a group of fast growing woody plant growing almost all over in India, except the Kashmir Valley. Bamboo forest constitutes about $13 \%$ of the total forest area of the country. The flowering of bamboo is typically of two types viz., (a) gregarious and (b) sporadic. In gregarious flowering, entire populations in a given area will bloom, with all clumps, and in all culms of the clumps, time of flowering may extend from a few months to a few years. In gregarious flowering, the affected clumps will invariably die. In sporadic flowering, not all culms in clumps will flower, or scattered sub sets of clumps of the population will flower. In sporadic flowering, when some culms flower, the affected culms will die, but there are species in which the clump will not die, but continue to produce healthy culms. Deogun (1937) has summarized all available knowledge regarding the flowering habit of Dendrocalamus strictus. He called it an "Irregularly flowering bamboo", based on his visit to bamboo forests in Uttar Pradesh, Orissa, Panjab and Madhya Pradesh. He reported that the physiological cycle of gregarious flowering of Dendrocalamus strictus in some localities was more than 65 years and might possibly be over a century. Chaturvedi 
(1988) reported the physiological cycle of Dendrocalamus strictus at long intervals of 20-65 years. Tatwawadi and Kali (1983) reported 35 years physiological cycle of Dendrocalamus strictus in Jarida range of East Melghat division of Maharashtra state. The average periodicity of physiological cycle of D. strictus in Allapalli, Chandrapur and Central Chanda division of Maharashtra was reported to be 43 years, 40.5 years and 40.5 years, respectively (Prabhu and Dabral, 1989). In Garhwal region, its gregarious flowering was reported by Gamble (1896) and Troup (1921). From Kalagarh, the gregarious flowering reported by Mathuda (1952) and Shah (1968) and from New Forest, Dehradun by Naithani (1993). The flowering culm may be of any age and may not necessarily be the oldest in the clump. The events of flowering were also recorded in seedlings of bamboo (Pathak, 1899; Birbal, 1899; Lauris, 1937; Ahmed, 1969). As per Troup (1921), the physiological cycle of Dendrocalamus strictus may be influenced to a slight extent by climatic and other causes, but primarily it is determined by physiological reasons. The bamboo resources in the country are shrinking day by day due to various reasons particularly gregarious flowering/seeding and subsequent dying. The flowering in bamboo is a rare phenomenon. Generally it occurs at long intervals. The period of physiological cycle (the period between two consecutive flowerings) is species-specific. The demand of bamboo has risen tremendously. For meeting the demand, it is therefore necessary to take steps to increase the yield of bamboo through developing rehabilitation techniques/guide lines for gregariously flowered bamboo areas. Notable contributions were made on gregariously flowered bamboo forests in India on various aspects of rehabilitation such as canopy manipulation by Hakeem (1985) grazing closure by Prasad (1985), soil working and other management aspects by Dwivedi (1988), Rajesh Gopal (1989) Prasad and Parihar (1994), RFRI (2002), GoI (2003), Goyal and Kishwan (2004), Kishwan and Goyal (2006), and Chaubey (2012). However, no scientific works reported in literature on effect of fire on rehabilitation of gregariously flowered bamboo forests. The present paper deals with the results of experiments pertaining to effect of successive ground fires and different periods of grazing closures in bamboo forests (flowered gregariously during 2005-2006) of south Seoni and north Balaghat forest divisions in the state of Madhya Pradesh, India (Map 1).

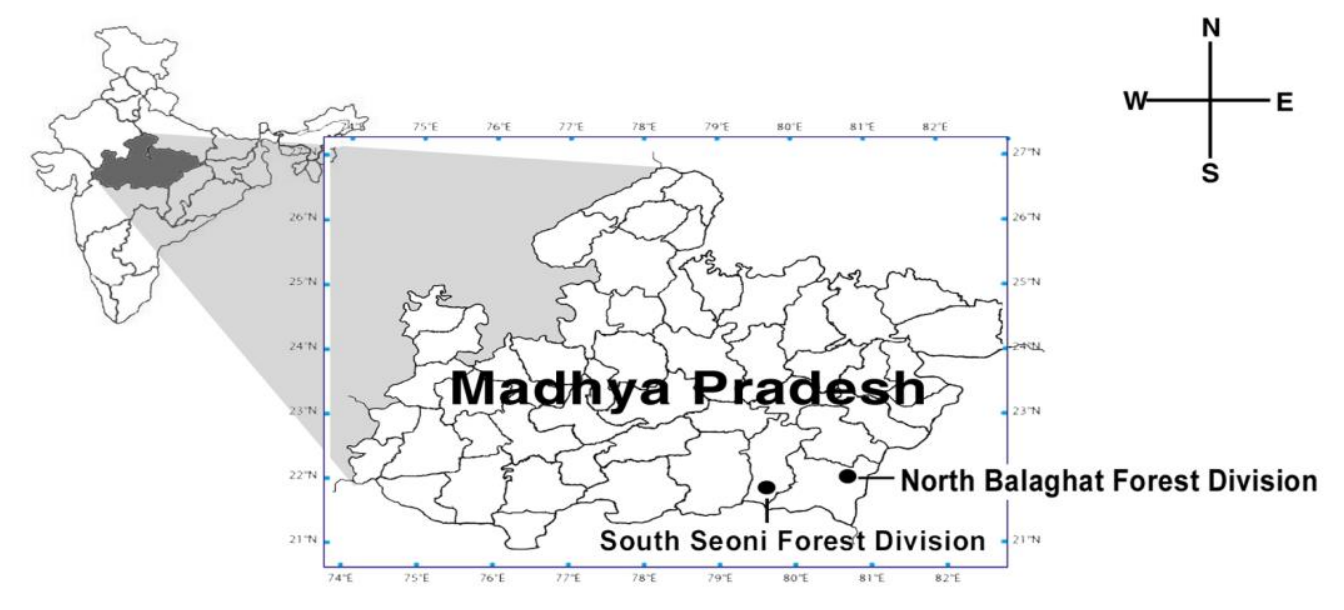

Map 1. India's map showing study sites in the state of Madhya Pradesh (M.P.) 


\section{Materials and Methods}

\subsection{Effect of Fire on Rehabilitation of Gregariously Flowered Bamboo Forests}

The fire treatments were undertakan at Rukhad range (Comptt. No. 419) of south Seoni forest division. The experiment included 03 treatments of artificial fire lit at different period viz., fire in March (F-1), fire in May (F-2), and fire in March and May (F-3). The ground fires lit for 2-3 hours periods annually for a period of five years from 2007 onwards. For comparison, control plot without fire was also taken for the same. The plot size for each treatment was of $50 \mathrm{~m}$ x $50 \mathrm{~m}$. Different fire plots were fenced using barbed wire.

\subsection{Effect of Grazing Closure on Rehabilitation of Gregariously Flowered Bamboo Forests}

The grazing closure treatments were undertaken at east Baihar range (Comptt. No. 1574) of north Balaghat forest division. This experiment includes 03 treatments of grazing closure at different period viz., (G-1) Three months grazing closure (July-Sept), (G-2) Six months grazing closure (July-Dec), and (G-3) Complete grazing closure for the five years. The observations on growth of regeneration, clump formation were recorded each year from 2007 onwards. For comparison, control plot open for grazing was also studied for the same. The plot size for each treatment was $50 \mathrm{~m}$ x $50 \mathrm{~m}$ undertaken at east Baihar range of north Balaghat forest division of Madhya Pradesh. The experimental area is moderately grazed. The plots in different treatments were fenced using barbed wire. The observations were recorded periodically at one year interval from 2007 to 2012.

\subsection{Statistical Analysis}

The randomized block design (RBD) was used. The plot size in all treatment was $50 \mathrm{mX50m}$. Each treatment was divided into three replicates of $16.66 \mathrm{~m} \mathrm{X} 16.66 \mathrm{~m}$ at each site. The observation of height and girth of each plant was taken in each treatment. The mean observation of plants in each replicate was considered for statistical analysis. Each replicate had equal number of observations. The parameters taken for statistical analysis were height increment, girth increment and production of number of culms clump ${ }^{-1}$ during the five years project period. The statistical analysis was made using SPSS software.

\section{Results and Discussion}

\subsection{Effect of Fire on Rehabilitation of Gregariously Flowered Bamboo Forests}

The observations on growth of regeneration and clump formation were recorded each year from 2007 to 2012 (Table 1). Perusal of data reveals that out of the three treatments of fires, fire in May gave better results in terms of height and girth increments of regeneration and clump formation. The height and girth increments in five years period with fire in May were found to be $460 \mathrm{~cm}$ and $7.75 \mathrm{~cm}$ respectively, followed by fire in March $(398 \mathrm{~cm}$ increase in height and $5.68 \mathrm{~cm}$ increase in girth). Two fire in a year i.e., fire in March and May, showed detrimental effect on culms growth (increase in height of $256 \mathrm{~cm}$ and girth of $3.80 \mathrm{~cm}$ ) and 
clump formation (5.65 culms clump $\left.{ }^{-1}\right)$. The average increase in height and girth after five years protection from fire (F-0) was found to be superior from F-3 (Two fire in March and May) with respect to height increment $(275 \mathrm{~cm})$, girth increment $(6.00 \mathrm{~cm})$ and the clump formation (6.00 culms clump ${ }^{-1}$ ) (Table 1).

\section{Table 1. Effect of Fire on Height and Girth Increment and Average Number of Culms Clump ${ }^{-1}$ of Bamboo Regeneration at Rukhad (2007- 12)}

\begin{tabular}{|c|c|c|c|c|c|c|c|c|c|c|c|c|c|c|c|}
\hline \multirow[t]{2}{*}{ Treatment } & \multicolumn{6}{|c|}{$\begin{array}{l}\text { Annual average height in } \\
\mathrm{cm} \\
(2007 \text { to } 2012)\end{array}$} & \multicolumn{6}{|c|}{$\begin{array}{c}\text { Annual average girth in } \\
\text { cm } \\
(2007 \text { to } 2012)\end{array}$} & \multirow{2}{*}{\multicolumn{2}{|c|}{\begin{tabular}{|c|c} 
Increaselncrease \\
in & in girth \\
height & $(\mathrm{cm})$ \\
$(\mathrm{cm})$ & during \\
during & five \\
five & years \\
years & \\
\end{tabular}}} & \multirow{2}{*}{$\begin{array}{c}\text { Average } \\
\text { no. of } \\
\text { culms } \\
\text { clump- } \\
\text { in } 2012\end{array}$} \\
\hline & 옹 & $\begin{array}{l}\infty \\
\text { ᄋ } \\
\text { ㄱ }\end{array}$ & 용 & 윰 & হ্ন & $\stackrel{N}{\sim}$ & ¿્̊ & 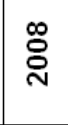 & : & 융 & $\underset{ }{\check{N}}$ & $\stackrel{N}{\sim}$ & & & \\
\hline $\begin{array}{c}\mathrm{F}-1 \\
\text { (Fire in } \\
\text { March) }\end{array}$ & 80 & 90 & 283 & 461 & 467 & 478 & 3.10 & 3.50 & 4.07 & 6.38 & 6.87 & 8.78 & $\begin{array}{c}398 \\
\pm 11.36 \\
\end{array}$ & $\begin{array}{c}5.68 \\
\pm 0.22\end{array}$ & $\begin{array}{c}7.91 \\
\pm 0.17\end{array}$ \\
\hline $\begin{array}{c}\mathrm{F}-2 \\
\text { (Fire in May) }\end{array}$ & 82 & 97 & 320 & 468 & 487 & 542 & 2.90 & 3.75 & 4.80 & 8.02 & 8.97 & $\begin{array}{c}10.6 \\
5\end{array}$ & $\begin{array}{c}460 \\
\pm 26.46\end{array}$ & $\begin{array}{c}7.75 \\
\pm 0.23\end{array}$ & $\begin{array}{c}8.60 \\
\pm 0.36\end{array}$ \\
\hline $\begin{array}{l}\text { F3 } \\
\text { (Fire in } \\
\text { March \& } \\
\text { May) }\end{array}$ & 104 & 93 & 266 & 287 & 308 & 360 & 3.00 & 3.20 & 3.50 & 3.65 & 5.10 & 6.80 & $\begin{array}{c}256 \\
\pm 15.62\end{array}$ & $\begin{array}{c}3.80 \\
\pm 0.18\end{array}$ & $\begin{array}{c}5.65 \\
\pm 0.02\end{array}$ \\
\hline $\begin{array}{c}\text { F-0 } \\
\text { (No fire) }\end{array}$ & 75 & 125 & 222 & 322 & 295 & 350 & 2.50 & 3.00 & 3.90 & 8.19 & 8.25 & 8.50 & $\begin{array}{c}275 \\
\pm 21.79\end{array}$ & $\begin{array}{c}6.00 \\
\pm 0.70\end{array}$ & $\begin{array}{c}6.00 \\
\pm 0.53\end{array}$ \\
\hline
\end{tabular}

Table 2 shows the descriptive statistics i.e. number of cases, mean, standard deviation, lower and upper bound at $95 \%$ confidence interval for mean, minimum and maximum values. The perusal of descriptive results reveals that treatments do differ in mean and range (i.e., maximum and minimum observation). One-way analysis of variance test for each parameter was taken for study. Perusal of data reveals that all treatments differ significantly for parameters under study at $95 \%$ level of significance. If the number 0.000 increases more than 0.05 the treatments may not differ significantly at $95 \%$ level of confidence. However, in this study, it is less than 0.05 . Hence, F- value in the adjoining column in more than the tabulated $\mathrm{F}$ value at $95 \%$ level of significance. So, it is clear that all treatments show significant difference from each other on different parameters in different replicates and treatments. Further, it can be concluded that height increment, girth increment and number of culms clump $^{-1}$ were significantly different between and within groups among various treatments. The four fire treatments viz; F1 (Fire in March), F2 (Fire in May), F3 (Fire in March \& May) and F0 (No fire) given in column 2 (I) were compared between the other groups as given in column $3(\mathrm{~J})$. The $*$ marks show that the mean difference is more than the critical difference at $95 \%$ significant level. The negative sign in the column of mean difference shows that treatment under comparison is inferior to other treatments. The positive sign indicates that the treatment is superior to other treatments under compared. Perusal of result indicated that treatment F2 (Fire in May) was the best among the other treatments in terms of height and girth increment and number of culms clump ${ }^{-1}$ (Figures $1,2 \& 3$ ). The mean difference is significant at the 0.05 level as compared to other treatments. The negative sign in control showed that the height and girth increment and number of culms clump ${ }^{-1}$ were inferior to the 
treated plots. In other words, different Fire treatment affects significantly the clump formation in bamboo.

\section{Table 2. Statistical Analysis (Descriptive, ANOVA and Post Hoc Test) for Fire Experiment}

\begin{tabular}{|c|c|c|c|c|c|c|c|c|c|}
\hline \multicolumn{10}{|c|}{ Descriptive } \\
\hline \multirow[b]{2}{*}{ Parameter } & \multirow[b]{2}{*}{$\begin{array}{l}\text { Treat } \\
\text { ment }\end{array}$} & \multirow[b]{2}{*}{$\mathrm{N}$} & \multirow[b]{2}{*}{ Mean } & \multirow[b]{2}{*}{$\begin{array}{c}\text { Std. } \\
\text { Deviation }\end{array}$} & \multirow[b]{2}{*}{ Std. Error } & \multicolumn{2}{|c|}{$\begin{array}{l}95 \% \text { Confidence } \\
\text { Interval for Mean }\end{array}$} & \multirow[b]{2}{*}{ Minimum } & \multirow[b]{2}{*}{ Maximum } \\
\hline & & & & & & $\begin{array}{l}\text { Lower } \\
\text { Bound }\end{array}$ & $\begin{array}{l}\text { Upper } \\
\text { Bound }\end{array}$ & & \\
\hline \multirow{5}{*}{$\begin{array}{l}\text { Height } \\
\text { increment }\end{array}$} & $\mathrm{F} 1$ & 3 & 398 & 11.358 & 6.557 & 369.786 & 426.214 & 385 & 406 \\
\hline & $\mathrm{F} 2$ & 3 & 460 & 26.458 & 15.275 & 394.276 & 525.724 & 440 & 490 \\
\hline & F3 & 3 & 256 & 15.621 & 9.019 & 217.197 & 294.804 & 246 & 274 \\
\hline & Fo & 3 & 275 & 21.794 & 12.583 & 220.860 & 329.141 & 250 & 290 \\
\hline & Total & 12 & 347.3 & 90.252 & 26.054 & 289.906 & 404.594 & 246 & 490 \\
\hline \multirow{5}{*}{$\begin{array}{l}\text { Girth } \\
\text { increment }\end{array}$} & $\mathrm{F} 1$ & 3 & 5.68 & 0.223 & 0.129 & 5.127 & 6.233 & 5.44 & 5.88 \\
\hline & $\mathrm{F} 2$ & 3 & 7.75 & 0.229 & 0.132 & 7.181 & 8.319 & 7.5 & 7.95 \\
\hline & F3 & 3 & 3.8 & 0.180 & 0.104 & 3.352 & 4.248 & 3.6 & 3.95 \\
\hline & Fo & 3 & 6 & 0.700 & 0.404 & 4.261 & 7.739 & 5.5 & 6.8 \\
\hline & Total & 12 & 5.808 & 1.502 & 0.434 & 4.853 & 6.762 & 3.6 & 7.95 \\
\hline \multirow{5}{*}{$\begin{array}{l}\text { No. of } \\
\text { culms } \\
\text { clump }^{-1} \text { in } \\
2012\end{array}$} & $\mathrm{~F} 1$ & 3 & 7.91 & 0.174 & 0.101 & 7.477 & 8.343 & 7.71 & 8.03 \\
\hline & $\mathrm{F} 2$ & 3 & 8.6 & 0.361 & 0.208 & 7.704 & 9.496 & 8.2 & 8.9 \\
\hline & F3 & 3 & 5.65 & 0.020 & 0.012 & 5.600 & 5.700 & 5.63 & 5.67 \\
\hline & Fo & 3 & 6 & 0.529 & 0.306 & 4.686 & 7.315 & 5.4 & 6.4 \\
\hline & Total & 12 & 7.04 & 1.331 & 0.384 & 6.194 & 7.886 & 5.4 & 8.9 \\
\hline
\end{tabular}

\begin{tabular}{|c|c|c|c|c|c|c|}
\hline \multicolumn{7}{|c|}{ ANOVA } \\
\hline & & $\begin{array}{l}\text { Sum of } \\
\text { Squares }\end{array}$ & df & $\begin{array}{l}\text { Mean } \\
\text { Square }\end{array}$ & $\mathbf{F}$ & Sig. \\
\hline \multirow[t]{3}{*}{ Height increment } & Between Groups & 86504.250 & 3 & 28834.750 & 74.508 & 0.000 \\
\hline & Within Groups & 3096.000 & 8 & 387.000 & & \\
\hline & Total & 89600.250 & 11 & & & \\
\hline \multirow[t]{3}{*}{ Girth increment } & Between Groups & 23.570 & 3 & 7.857 & 50.315 & 0.000 \\
\hline & Within Groups & 1.249 & 8 & 0.156 & & \\
\hline & Total & 24.819 & 11 & & & \\
\hline \multirow{3}{*}{$\begin{array}{l}\text { No. of culms clump }{ }^{-1} \text { in } \\
2012\end{array}$} & Between Groups & 18.613 & 3 & 6.204 & 56.299 & 0.000 \\
\hline & Within Groups & 0.882 & 8 & 0.110 & & \\
\hline & Total & 19.494 & 11 & & & \\
\hline
\end{tabular}


Post Hoc Tests

\begin{tabular}{|c|c|c|c|c|c|c|c|}
\hline \multicolumn{8}{|c|}{ Multiple Comparisons } \\
\hline \multicolumn{8}{|c|}{ LSD } \\
\hline \multirow[b]{2}{*}{$\begin{array}{c}\text { Dependent } \\
\text { Variable }\end{array}$} & \multirow[b]{2}{*}{$\begin{array}{c}\text { (I) } \\
\text { Treatment }\end{array}$} & \multirow[b]{2}{*}{$\begin{array}{c}\text { (J) } \\
\text { Treatment }\end{array}$} & \multirow{2}{*}{$\begin{array}{c}\text { Mean } \\
\text { Difference } \\
(\mid-J)\end{array}$} & \multirow[b]{2}{*}{$\begin{array}{l}\text { Std. } \\
\text { Error }\end{array}$} & \multirow[b]{2}{*}{ Sig. } & \multicolumn{2}{|c|}{$\begin{array}{c}95 \% \text { Confidence } \\
\text { Interval }\end{array}$} \\
\hline & & & & & & $\begin{array}{l}\text { Lower } \\
\text { Bound }\end{array}$ & $\begin{array}{l}\text { Upper } \\
\text { Bound }\end{array}$ \\
\hline \multirow{12}{*}{$\begin{array}{l}\text { Height } \\
\text { increment }\end{array}$} & \multirow[t]{3}{*}{ F1 } & $\mathrm{F} 2$ & $-62.000^{\circ}$ & 16.062 & 0.010 & -99.04 & -24.960 \\
\hline & & F3 & $142.000^{\circ}$ & 16.062 & 0.000 & 104.96 & 179.040 \\
\hline & & F0 & $123.000^{\circ}$ & 16.062 & 0.000 & 85.96 & 160.040 \\
\hline & \multirow[t]{3}{*}{ F2 } & F1 & $62.000^{*}$ & 16.062 & 0.010 & 24.96 & 99.040 \\
\hline & & F3 & $204.000^{\circ}$ & 16.062 & 0.000 & 166.96 & 241.040 \\
\hline & & F0 & $185.000^{\circ}$ & 16.062 & 0.000 & 147.96 & 222.040 \\
\hline & \multirow[t]{3}{*}{ F3 } & F1 & $-142.000^{\circ}$ & 16.062 & 0.000 & -179.04 & -104.960 \\
\hline & & F2 & $-204.000^{\circ}$ & 16.062 & 0.000 & -241.04 & -166.960 \\
\hline & & F0 & -19.000 & 16.062 & 0.270 & -56.04 & 18.040 \\
\hline & \multirow[t]{3}{*}{ F0 } & F1 & $-123.000^{\circ}$ & 16.062 & 0.000 & -160.04 & -85.960 \\
\hline & & F2 & $-185.000^{*}$ & 16.062 & 0.000 & -222.04 & -147.960 \\
\hline & & F3 & 19.000 & 16.062 & 0.270 & -18.04 & 56.040 \\
\hline \multirow{12}{*}{$\begin{array}{l}\text { Girth } \\
\text { increment }\end{array}$} & \multirow[t]{3}{*}{ F1 } & F2 & $-2.070^{*}$ & 0.323 & 0.000 & -2.814 & -1.326 \\
\hline & & F3 & $1.880^{\circ}$ & 0.323 & 0.000 & 1.136 & 2.624 \\
\hline & & F0 & -0.320 & 0.323 & 0.350 & -1.064 & 0.424 \\
\hline & \multirow[t]{3}{*}{ F2 } & F1 & $2.070^{\circ}$ & 0.323 & 0.000 & 1.326 & 2.814 \\
\hline & & F3 & $3.950^{\circ}$ & 0.323 & 0.000 & 3.206 & 4.694 \\
\hline & & F0 & $1.750^{\circ}$ & 0.323 & 0.000 & 1.006 & 2.494 \\
\hline & \multirow[t]{3}{*}{ F3 } & F1 & $-1.880^{\circ}$ & 0.323 & 0.000 & -2.624 & -1.136 \\
\hline & & F2 & $-3.950^{\circ}$ & 0.323 & 0.000 & -4.694 & -3.206 \\
\hline & & F0 & $-2.200^{*}$ & 0.323 & 0.000 & -2.944 & -1.456 \\
\hline & \multirow[t]{3}{*}{ F0 } & F1 & 0.320 & 0.323 & 0.350 & -0.424 & 1.064 \\
\hline & & F2 & $-1.750^{\circ}$ & 0.323 & 0.000 & -2.494 & -1.006 \\
\hline & & F3 & $2.200^{\circ}$ & 0.323 & 0.000 & 1.456 & 2.944 \\
\hline \multirow{12}{*}{$\begin{array}{l}\text { No. of } \\
\text { culms } \\
\text { clump }^{-1} \text { in } \\
2012\end{array}$} & \multirow[t]{3}{*}{ F1 } & F2 & $-690^{\circ}$ & 0.271 & 0.030 & -1.315 & -0.065 \\
\hline & & F3 & $2.260^{*}$ & 0.271 & 0.000 & 1.635 & 2.885 \\
\hline & & F0 & $1.910^{\circ}$ & 0.271 & 0.000 & 1.285 & 2.535 \\
\hline & \multirow[t]{3}{*}{ F2 } & F1 & $0.690^{\circ}$ & 0.271 & 0.030 & 0.065 & 1.315 \\
\hline & & F3 & $2.950^{\circ}$ & 0.271 & 0.000 & 2.325 & 3.575 \\
\hline & & F0 & $2.600^{\circ}$ & 0.271 & 0.000 & 1.975 & 3.225 \\
\hline & \multirow[t]{3}{*}{ F3 } & F1 & $-2.260^{\circ}$ & 0.271 & 0.000 & -2.885 & -1.635 \\
\hline & & F2 & $-2.950^{\circ}$ & 0.271 & 0.000 & -3.575 & -2.325 \\
\hline & & F0 & -0.350 & 0.271 & 0.230 & -0.975 & 0.275 \\
\hline & \multirow[t]{3}{*}{ F0 } & F1 & $-1.910^{*}$ & 0.271 & 0.000 & -2.535 & -1.285 \\
\hline & & F2 & $-2.600^{\circ}$ & 0.271 & 0.000 & -3.225 & -1.975 \\
\hline & & F3 & 0.350 & 0.271 & 0.230 & -0.275 & 0.975 \\
\hline
\end{tabular}

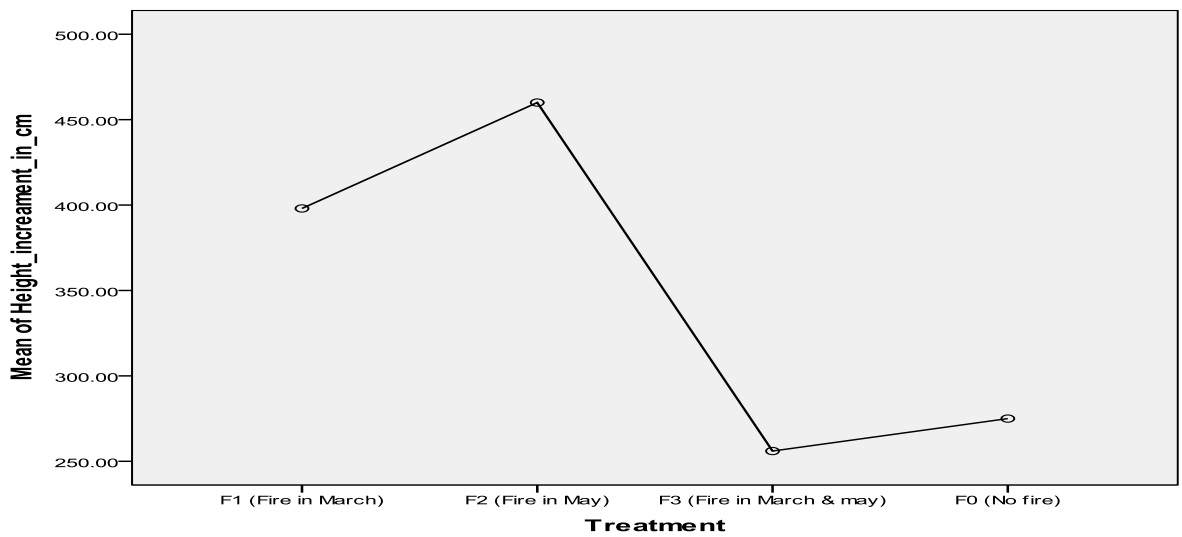

Figure 1. Showing Effect of Fire in Terms of Increment in Mean Height 


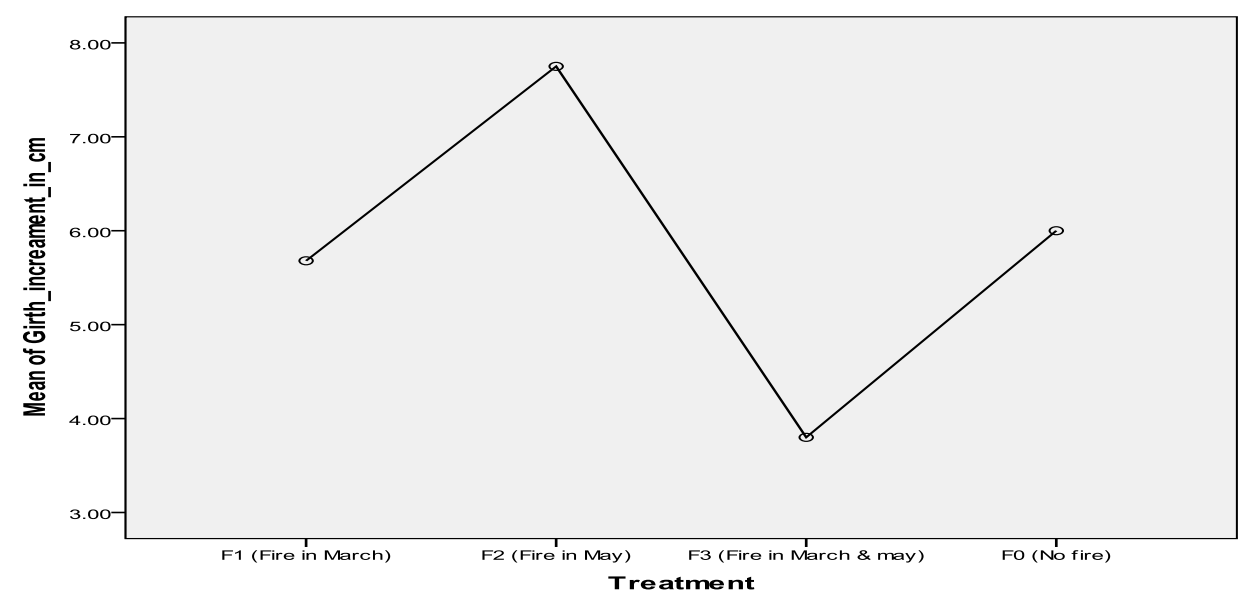

Figure 2. Showing Effect of Fire in Terms of Increment in Mean Girth

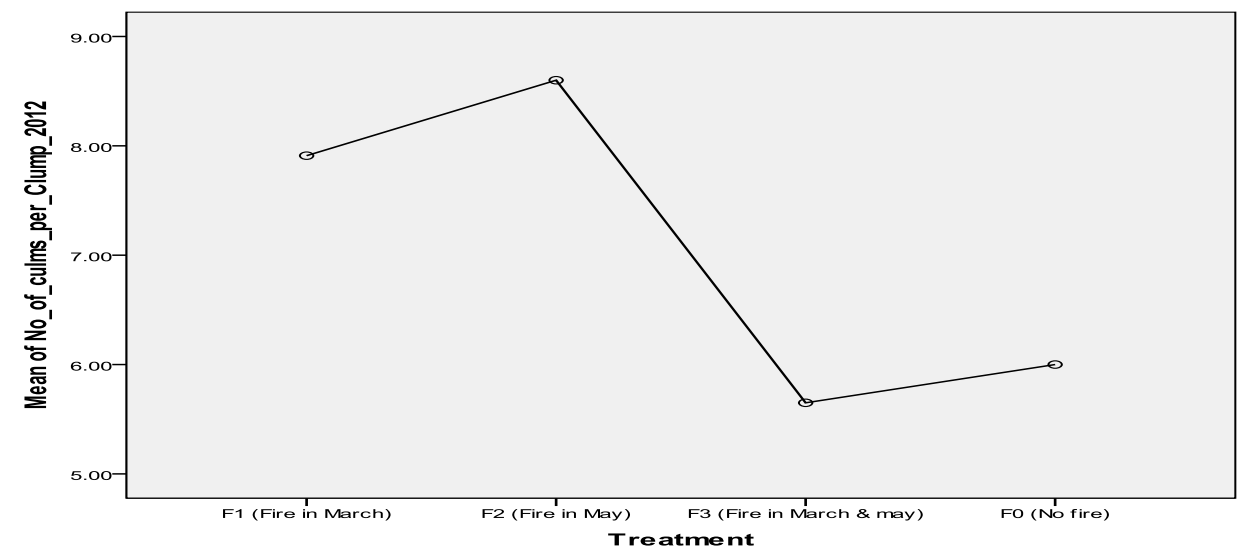

Figure 3. Showing Effect of Fire in Terms of Production of Mean Number of Culms Clump ${ }^{-1}$

\subsection{Effect of Grazing Closure on Rehabilitation of Gregariously Flowered Bamboo Forests}

Perusal of data (Table-3) reveals that out of the three treatments of grazing closures, complete closure gave better results in terms of height and girth increment of regeneration and other growth parameters of clump formation, followed by six months and three months grazing closures. The height and girth increments in five years period with complete closure were found to be $345 \mathrm{~cm}$ and $6.42 \mathrm{~cm}$, respectively, along with 6.45 culms clump $^{-1}$, followed by six months closure $(327 \mathrm{~cm}$ increase in height, $6.35 \mathrm{~cm}$ increase in girth and $5.66 \mathrm{culms}$ clump $^{-1}$ ) and three months closure (299 cm increase in height, $5.54 \mathrm{~cm}$ increase in girth and 3.75 culms clump $^{-1}$ ). The average increase in height and girth in open plot (free for grazing) after five years (G-0) was found to be $237 \mathrm{~cm}$ and $4.68 \mathrm{~cm}$, respectively with the clump formation of 3.62 culms clump $^{-1}$. The data indicates that grazing closure is beneficial for the growth of culms and clump formation. 


\section{Table 3. Effect of Grazing Closure on Height and Girth Increment and Average Number of Culms Clump ${ }^{-1}$ of Bamboo Regeneration at East Baihar Range of North Balaghat Division (2007-12)}

\begin{tabular}{|c|c|c|c|c|c|c|c|c|c|c|c|c|c|c|c|}
\hline \multirow[t]{2}{*}{ Treatment } & \multicolumn{6}{|c|}{$\begin{array}{c}\text { Annual average height in } \\
\text { cm } \\
\text { (2007 to 2012) }\end{array}$} & \multicolumn{6}{|c|}{$\begin{array}{l}\text { Annual average girth in } \mathrm{cm} \\
\text { (2007 to 2012) }\end{array}$} & \multirow{2}{*}{\multicolumn{2}{|c|}{\begin{tabular}{|c|c|} 
Increase & Increase \\
in & in girth \\
height & (cm) \\
(cm) & during \\
during & five \\
five & years \\
years & \\
\end{tabular}}} & \multirow{2}{*}{$\begin{array}{l}\text { Average } \\
\text { no. of } \\
\text { culms } \\
\text { clump }^{-1} \\
\text { in } 2012\end{array}$} \\
\hline & 옹 & $\stackrel{\infty}{\circ}$ & 용 & 융 & 동 & $\stackrel{\text { N }}{\text { ஸ }}$ & 용 & 足 & 옴 & 음 & হ্ণ & $\stackrel{\text { N }}{\text { ஸे }}$ & & & \\
\hline $\begin{array}{l}\text { G-1 } \\
\text { (3- Months } \\
\text { from July to } \\
\text { September) }\end{array}$ & 31 & 39 & 147 & 199 & 260 & 330 & 0.60 & 1.10 & 2.10 & 3.20 & 4.95 & 6.14 & $\begin{array}{c}299 \\
\pm 33.81\end{array}$ & $\begin{array}{c}5.54 \\
\pm 0.16\end{array}$ & $\begin{array}{l}3.75 \\
\pm 0.39\end{array}$ \\
\hline $\begin{array}{l}\text { G-2 } \\
\text { (6- Months } \\
\text { from July to } \\
\text { December) }\end{array}$ & 27 & 49 & 171 & 237 & 290 & 354 & 0.50 & 1.85 & 2.80 & 4.42 & 5.50 & 6.85 & $\begin{array}{c}327 \\
\pm 10.82\end{array}$ & $\begin{array}{c}6.35 \\
\pm 0.13\end{array}$ & $\begin{array}{c}5.66 \\
\pm 0.18\end{array}$ \\
\hline $\begin{array}{c}\text { G-3 } \\
\text { (12 - Months } \\
\text { from July to } \\
\text { June) }\end{array}$ & 30 & 56 & 182 & 247 & 330 & 375 & 0.50 & 2.10 & 3.10 & 4.47 & 5.90 & 6.92 & $\begin{array}{c}345 \\
\pm 10.44\end{array}$ & $\begin{array}{l}6.42 \\
\pm 0.13\end{array}$ & $\begin{array}{c}6.45 \\
\pm 0.22\end{array}$ \\
\hline $\begin{array}{c}\text { G-0 } \\
\text { (Open for } \\
\text { grazing) }\end{array}$ & 33 & 49 & 120 & 177 & 220 & 270 & 0.80 & 0.80 & 1.60 & 2.80 & 4.35 & 5.48 & $\begin{array}{c}237 \\
\pm 10.82 \\
\end{array}$ & $\begin{array}{c}4.68 \\
\pm 0.23 \\
\end{array}$ & $\begin{array}{c}3.62 \\
\pm 0.46 \\
\end{array}$ \\
\hline
\end{tabular}

Table 4 shows the descriptive statistics i.e. number of cases, mean, standard deviation, lower and upper bound at $95 \%$ confidence interval for mean, minimum and maximum values. The treatment wise observations for each parameter such as height increment, girth increment and number of culms clump ${ }^{-1}$ during the five years period were taken. The perusal of descriptive results reveals that treatments do differ in mean and range (i.e., maximum and minimum observation). One-way analysis of variance test for each parameter taken for study reveals that all treatments differ significantly for parameters under study at $95 \%$ level of significance. If the number 0.000 increases more than 0.05 the treatments may not differ significantly at $95 \%$ level of confidence. However, in the study site, it is less than 0.05 , Hence, $f$ value in the adjoining column in more than the tabulated $F$ value at $95 \%$ level of significance. So, it is clear that all treatments show significant difference from each other on different parameters in different replicates and treatments. Further, it can be concluded that height increment, girth increment and No. of culms clump ${ }^{-1}$ were significantly different between and within groups among various treatments. After determining that all treatments are different, we should know which the best treatment for the parameters of interest is. To establish one treatment as the best among the lot, we have to compare it with others based on critical difference. If one treatment is the best among the group, its mean difference with any other should be more than the critical difference. Spacing treatments at different intervals are compared with each other with reference to increment in height, girth and number of culms clump $^{-1}$ during the five years study period. In the first column, the dependent variable is shown as height increment, girth increment and number of culms clump ${ }^{-1}$. The four grazing closures viz; G1 (July to Sept 3 month), G2 (July to December), G3 (Total closure for the project period) and G0 (Open for grazing) given in column 2 (I) were compared between the other groups as given in column $3(\mathrm{~J})$. The $*$ marks show that the mean difference is more 
than the critical difference at $95 \%$ significant level. The negative sign in the column of mean difference shows that treatment under comparison is inferior to other treatments. The positive sign indicates that the treatment is superior to other treatments under compared. Perusal of results indicated that treatment G3 (July to June for the total project period) was the best among the other treatments in terms of height and girth increment and number of culms clump $^{-1}$ (Figure $4,5 \& 6$ ). The mean difference is significant at the 0.05 level as compared to other treatments. The negative sign in control showed that the height and girth increment and number of culms clump ${ }^{-1}$ were inferior to the treated plots. In other words, different grazing closure affects significantly the clump formation in bamboo.

Table 4. Statistical Analysis (Descriptive, ANOVA and Post Hoc Test) for
Grazing Closure Experiment

\begin{tabular}{|c|c|c|c|c|c|c|c|c|c|}
\hline \multicolumn{10}{|c|}{ Descriptive } \\
\hline \multirow{2}{*}{ Parameter } & \multirow{2}{*}{ Treatment } & \multirow[b]{2}{*}{$\mathbf{N}$} & \multirow[b]{2}{*}{ Mean } & \multirow[b]{2}{*}{$\begin{array}{c}\text { Std. } \\
\text { Deviation }\end{array}$} & \multirow[b]{2}{*}{$\begin{array}{l}\text { Std. } \\
\text { Error }\end{array}$} & \multicolumn{2}{|c|}{$\begin{array}{l}\text { 95\% Confidence } \\
\text { Interval for Mean }\end{array}$} & \multirow[b]{2}{*}{ Minimum } & \multirow[b]{2}{*}{$\begin{array}{l}\text { Maxi } \\
\text { mum }\end{array}$} \\
\hline & & & & & & $\begin{array}{l}\text { Lower } \\
\text { Bound }\end{array}$ & $\begin{array}{l}\text { Upper } \\
\text { Bound }\end{array}$ & & \\
\hline \multirow{5}{*}{$\begin{array}{c}\text { Height } \\
\text { increment }\end{array}$} & G1 & 3 & 299 & 33.81 & 19.52 & 215.02 & 382.98 & 260 & 320 \\
\hline & G2 & 3 & 327 & 10.82 & 6.25 & 300.13 & 353.87 & 315 & 336 \\
\hline & G3 & 3 & 345 & 10.44 & 6.03 & 319.06 & 370.94 & 333 & 352 \\
\hline & G0 & 3 & 237 & 10.82 & 6.25 & 210.13 & 263.87 & 225 & 246 \\
\hline & Total & 12 & 302 & 45.82 & 13.23 & 272.89 & 331.11 & 225 & 352 \\
\hline \multirow{5}{*}{$\begin{array}{c}\text { Girth } \\
\text { increment }\end{array}$} & G1 & 3 & 5.54 & 0.16 & 0.09 & 5.15 & 5.93 & 5.38 & 5.69 \\
\hline & G2 & 3 & 6.35 & 0.13 & 0.08 & 6.02 & 6.68 & 6.25 & 6.50 \\
\hline & G3 & 3 & 6.42 & 0.13 & 0.08 & 6.10 & 6.74 & 6.27 & 6.50 \\
\hline & G0 & 3 & 4.68 & 0.23 & 0.13 & 4.12 & 5.24 & 4.42 & 4.84 \\
\hline & Total & 12 & 5.75 & 0.75 & 0.22 & 5.27 & 6.23 & 4.42 & 6.50 \\
\hline \multirow{5}{*}{$\begin{array}{c}\text { No. of } \\
\text { culms } \\
\text { clump }^{-1} \text { in } \\
2012\end{array}$} & G1 & 3 & 3.75 & 0.39 & 0.23 & 2.78 & 4.72 & 3.36 & 4.14 \\
\hline & G2 & 3 & 5.66 & 0.18 & 0.10 & 5.22 & 6.10 & 5.46 & 5.80 \\
\hline & G3 & 3 & 6.45 & 0.22 & 0.13 & 5.91 & 6.99 & 6.30 & 6.70 \\
\hline & G0 & 3 & 3.62 & 0.46 & 0.26 & 2.49 & 4.75 & 3.10 & 3.95 \\
\hline & Total & 12 & 4.87 & 1.30 & 0.38 & 4.04 & 5.70 & 3.10 & 6.70 \\
\hline
\end{tabular}

\begin{tabular}{|c|c|c|c|c|c|c|}
\hline \multicolumn{7}{|c|}{ ANOVA } \\
\hline & & $\begin{array}{l}\text { Sum of } \\
\text { Squares }\end{array}$ & df & $\begin{array}{l}\text { Mean } \\
\text { Square }\end{array}$ & $\mathbf{F}$ & Sig. \\
\hline \multirow{3}{*}{$\begin{array}{l}\text { Height } \\
\text { increment }\end{array}$} & Between Groups & 20124 & 3 & 6708.000 & 18.057 & 0.001 \\
\hline & Within Groups & 2972 & 8 & 371.500 & & \\
\hline & Total & 23096 & 11 & & & \\
\hline \multirow[t]{3}{*}{ Girth increment } & Between Groups & 5.994 & 3 & 1.998 & 72.584 & 0.000 \\
\hline & Within Groups & 0.220 & 8 & 0.028 & & \\
\hline & Total & 6.214 & 11 & & & \\
\hline \multirow{3}{*}{$\begin{array}{l}\text { No. of culms } \\
\text { clump-1 in } 2012\end{array}$} & Between Groups & 17.812 & 3 & 5.937 & 54.112 & 0.000 \\
\hline & Within Groups & 0.878 & 8 & 0.110 & & \\
\hline & Total & 18.690 & 11 & & & \\
\hline
\end{tabular}


Post Hoc Tests

\begin{tabular}{|c|c|c|c|c|c|c|c|}
\hline \multicolumn{8}{|c|}{ Multiple Comparisons } \\
\hline \multicolumn{8}{|l|}{ LSD } \\
\hline \multirow[b]{2}{*}{$\begin{array}{l}\text { Dependent } \\
\text { Variable }\end{array}$} & \multirow[b]{2}{*}{$\begin{array}{c}\text { (I) } \\
\text { Treatment }\end{array}$} & \multirow[b]{2}{*}{$\begin{array}{c}(\mathrm{J}) \\
\text { Treatment }\end{array}$} & \multirow{2}{*}{$\begin{array}{c}\text { Mean } \\
\text { Difference } \\
(\mathrm{I}-\mathrm{J})\end{array}$} & \multirow[b]{2}{*}{$\begin{array}{l}\text { Std. } \\
\text { Error }\end{array}$} & \multirow[b]{2}{*}{ Sig. } & \multicolumn{2}{|c|}{ 95\% Confidence Interval } \\
\hline & & & & & & $\begin{array}{l}\text { Lower } \\
\text { Bound }\end{array}$ & $\begin{array}{l}\text { Upper } \\
\text { Bound }\end{array}$ \\
\hline \multirow{12}{*}{$\begin{array}{c}\text { Height } \\
\text { increment }\end{array}$} & \multirow[t]{3}{*}{ G1 } & G2 & -28.000 & 15.737 & 0.113 & -64.291 & 8.291 \\
\hline & & G3 & $-46.000^{\circ}$ & 15.737 & 0.019 & -82.291 & -9.709 \\
\hline & & G0 & $62.000^{\circ}$ & 15.737 & 0.004 & 25.709 & 98.291 \\
\hline & \multirow[t]{3}{*}{ G2 } & G1 & 28.000 & 15.737 & 0.113 & -8.291 & 64.291 \\
\hline & & G3 & -18.000 & 15.737 & 0.286 & -54.291 & 18.291 \\
\hline & & G0 & $90.000^{\circ}$ & 15.737 & 0.000 & 53.709 & 126.291 \\
\hline & \multirow[t]{3}{*}{ G3 } & G1 & $46.000^{\circ}$ & 15.737 & 0.019 & 9.709 & 82.291 \\
\hline & & G2 & 18.000 & 15.737 & 0.286 & -18.291 & 54.291 \\
\hline & & G0 & $108.000^{\circ}$ & 15.737 & 0.000 & 71.709 & 144.291 \\
\hline & \multirow[t]{3}{*}{ G0 } & G1 & $-62.000^{\circ}$ & 15.737 & 0.004 & -98.291 & -25.709 \\
\hline & & G2 & $-90.000^{\circ}$ & 15.737 & 0.000 & -126.291 & $\begin{array}{l}-53.709 \\
\end{array}$ \\
\hline & & G3 & $-108.000^{\circ}$ & 15.737 & 0.000 & -144.291 & -71.709 \\
\hline \multirow{12}{*}{$\begin{array}{c}\text { Girth } \\
\text { increment }\end{array}$} & \multirow[t]{3}{*}{ G1 } & G2 & $-0.810^{*}$ & 0.135 & 0.000 & -1.122 & -0.498 \\
\hline & & G3 & $-0.880^{\circ}$ & 0.135 & 0.000 & -1.192 & -0.568 \\
\hline & & G0 & $0.8600^{\circ}$ & 0.135 & 0.000 & 0.548 & 1.172 \\
\hline & \multirow[t]{3}{*}{ G2 } & G1 & $0.810^{\circ}$ & 0.135 & 0.000 & 0.498 & 1.122 \\
\hline & & G3 & -0.070 & 0.135 & 0.619 & -0.382 & 0.242 \\
\hline & & G0 & $1.670^{\circ}$ & 0.135 & 0.000 & 1.358 & 1.982 \\
\hline & \multirow[t]{3}{*}{ G3 } & G1 & $0.880^{\circ}$ & 0.135 & 0.000 & 0.568 & 1.192 \\
\hline & & G2 & 0.070 & 0.135 & 0.619 & -0.242 & 0.382 \\
\hline & & G0 & $1.740^{\circ}$ & 0.135 & 0.000 & 1.428 & 2.052 \\
\hline & \multirow[t]{3}{*}{ G0 } & G1 & $-0.860^{\circ}$ & 0.135 & 0.000 & -1.172 & -0.548 \\
\hline & & G2 & $-1.670^{\circ}$ & 0.135 & 0.000 & -1.982 & -1.358 \\
\hline & & G3 & $-1.740^{\circ}$ & 0.135 & 0.000 & -2.052 & -1.428 \\
\hline \multirow{12}{*}{$\begin{array}{l}\text { No. of culms } \\
\text { clump }{ }^{-1} \text { in } \\
2012\end{array}$} & \multirow[t]{3}{*}{ G1 } & G2 & $-1.910^{\circ}$ & 0.270 & 0.000 & -2.534 & -1.286 \\
\hline & & G3 & $-2.700^{\circ}$ & 0.270 & 0.000 & -3.324 & -2.076 \\
\hline & & G0 & 0.1300 & 0.270 & 0.644 & -0.494 & 0.754 \\
\hline & \multirow[t]{3}{*}{ G2 } & G1 & $1.910^{\circ}$ & 0.270 & 0.000 & 1.286 & 2.534 \\
\hline & & G3 & $-0.790^{\circ}$ & 0.270 & 0.019 & -1.414 & -0.166 \\
\hline & & G0 & $2.04000^{\circ}$ & 0.270 & 0.000 & 1.416 & 2.664 \\
\hline & \multirow[t]{3}{*}{ G3 } & G1 & $2.700^{\circ}$ & 0.270 & 0.000 & 2.076 & 3.324 \\
\hline & & G2 & $0.7900^{\circ}$ & 0.270 & 0.019 & 0.166 & 1.414 \\
\hline & & G0 & $2.83000^{\circ}$ & 0.270 & 0.000 & 2.206 & 3.454 \\
\hline & \multirow[t]{3}{*}{ G0 } & $\mathrm{G} 1$ & -0.130 & 0.270 & 0.644 & -0.754 & 0.494 \\
\hline & & G2 & $-2.040^{\circ}$ & 0.270 & 0.000 & -2.664 & -1.416 \\
\hline & & G3 & $-2.830^{\circ}$ & 0.270 & 0.000 & -3.454 & -2.206 \\
\hline
\end{tabular}

${ }^{\star}$. The mean difference is significant at the 0.05 level. 


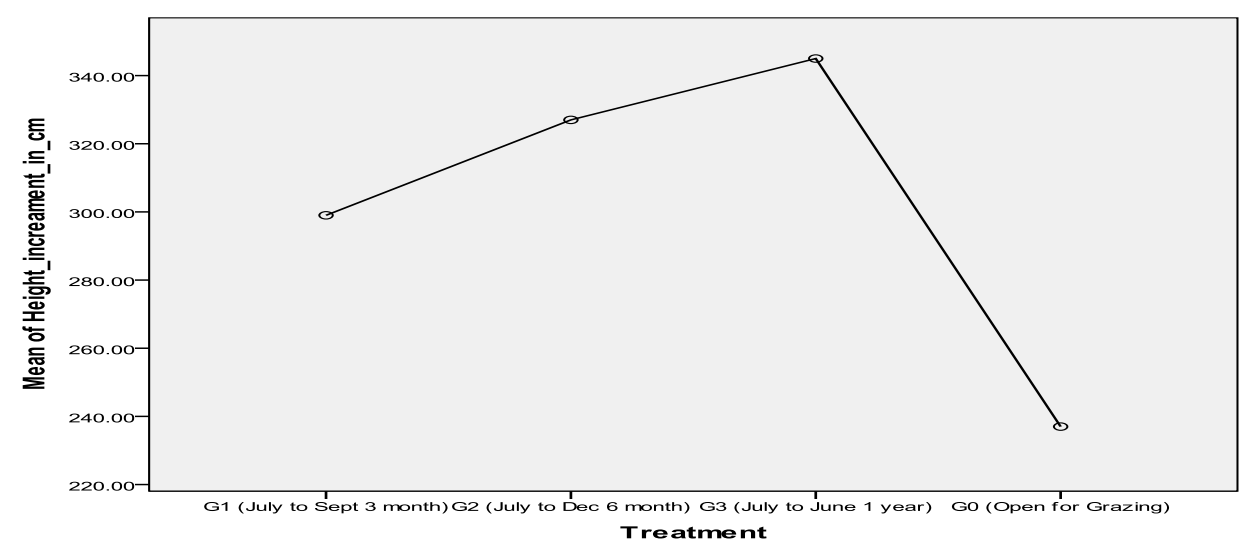

Figure 4. Showing Effect of Grazing Closure in Terms of Increment in Mean Height

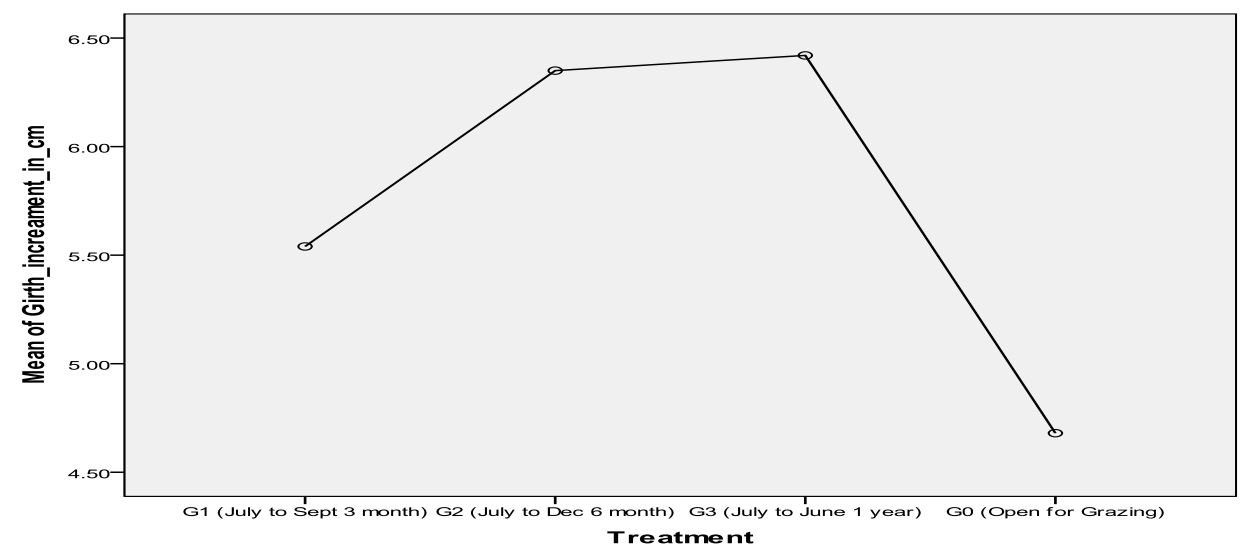

Figure 5. Showing Effect of Grazing Closure in Terms of increment in Mean Girth

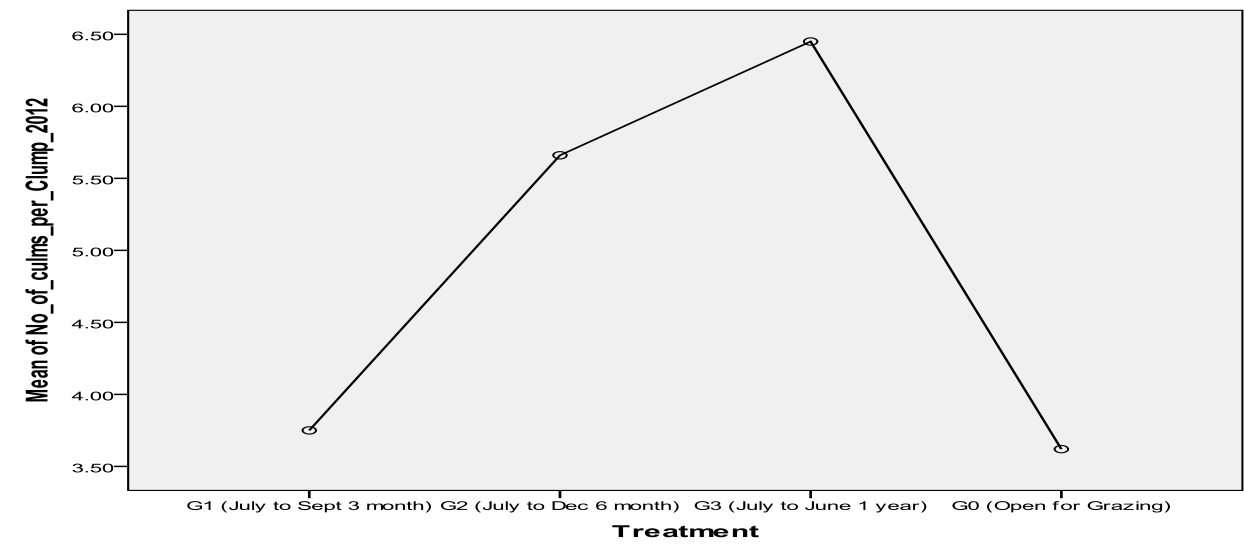

Figure 6. Showing Effect of Grazing Closure in Terms of Production of Mean Number of Culms Clump $^{-1}$

The root stock of bamboo (Dendrocalamus strictus) consists of a dense mass of short rhizomes in which the nodes are close to each other and provided with clusters of small 
rootlets. In addition, there are one or more eyes at every node which may develop into new rhizomes, and subsequently into new culms but mostly remain dormant. The stimulating effect of fire on culms and clump formation is primarily due to thinning out process of dense natural regeneration, and subsequently in development of more vigorous culms and clumps, as the new rhizomes and their culms have everywhere enough room to develop. Action of fire also stimulates the clump formation due to activation of some dormant buds, which may develop into new culms. The role of protection enjoyed by the grazing- closure leads to ameliorating the physical, chemical and biological conditions of the site. This could be attributed to the development and enhancement of number of culms clump ${ }^{-1}$.

\section{Conclusion}

Whereas bamboo (Dendrocalamus strictus) is found occurring widely in different tropical forest of the country, which apart from being a source of livelihood of forest dependent population and in industry, its ecological role in Sustainable Forest Management requires greater attention. Based on experimental findings, the following conclusions are drawn:-

1. Apart from establishment of ex-situ rhizome banks, establishment of in-situ rhizome banks should be encouraged.

2. The rehabilitation activities to promote clump formation should be initiated after $2-3$ years of flowering period while elite formation get started.

3. The single ground fire treatment either in March or in May in a year prove beneficial for natural pruning of dense bamboo carpet and gave better growth than protection from fire up to 5 years period. The fire stimulates the growth of bamboo and greater production of new culms. Thus, during initial period of rehabilitation while elites are formed, natural surface fire for 2-3 hours is recommended, provided that area is completely protected from grazing and other biotic factors.

4. The complete grazing closure for at least five years period is recommended to stimulate growth of bamboo seedlings and formation of clumps.

\section{References}

[1] M. Ahmed, "Flowering of seedlings of Dendrocalamus strictus", Indian Forester, vol. 95, (1964), pp. 214.

[2] A. A. Ansari, O. P. Chaubey, A. Sharma and A. Pandey, "Hand book of bamboos with particular reference to Madhya Pradesh", SFRI bulletin, no. 45, (2002), pp. 1-53.

[3] B. Birbal, "The flowering of seedlings of Dendrocalamus strictus", Indian Forester, vol. 25, (1899), pp. 305306.

[4] A. N. Chaturvedi, "Management of bamboo forests", Indian Forester, vol. 114, no. 9, (1988), pp. 489-495.

[5] O. P. Chaubey, "Impact assessment of different treatments on rehabilitation of gregariously flowered bamboo areas in Madhya Pradesh", Final report submitted to the M.P. Forest Department, Bhopal, (2012), pp $1-121$.

[6] P. N. Deogun, "The Silviculture and management of the bamboo Dendrocalamus strictus", Indian Forest Records (NS) Silviculture, II, vol. 4, (1937), pp. 1-173.

[7] A. P. Dwivedi, "Gregarious flowering in Dendrocalamus srtictus in Shahdol (M.P.) Some management considerations", Indian Forester, vol. 114, no. 9, (1988).

[8] J. S. Gamble, "Bambuseae of British India", Ann.Roy.Bot.Grad., Calcutta, vol. 7, (1896), pp. 1-133.

[9] GoI, Recommendations "Task Force on Regeneration", constituted by the Steering Committee on Gregarious Flowering of Muli bamboo in North -East, MOEF, GoI, New Delhi. (Internal Notes), (2003).

[10] A. K. Goyal and J. Kishwan, "Gregarious Flowering of bamboo in North-East India", Some Management Issues, XI World Bamboo Congress, New Delhi, (2004) February.

[11] K. L. Hakeem, "Rehabilitation of flowered bamboo areas of Jabalpur", Journal of Tropical Forestry, vol. 1, no. 1 , (1985), pp. 70-78. 
[12] J. Kishwan and A. K. Goyal, "Gregarious flowering of Bamboos in North-East India-Need for Intensive Management", Indian Forester, vol. 134, no. 5, (2006), pp. 525-533.

[13] M. V. Lauris, “Two years old bamboo seedling”, Indian Forester, vol. 63, (1937), pp. 857.

[14] G. S. Mathuda, "Flowering habit of the bamboo", Dendrocalamus strictus, Indian Forester, vol. 78, (1952), pp. 86-88.

[15] H. B. Naithani, "Contributions to the taxonomic studies of Indian bamboos", Ph.D Thesis, Garhvwal University, Srinagar, vol. 2, (1993), pp. 278.

[16] P. L. S. Pathak, "Seedlings of Dendrocalamus strictus in flower", Indian Forester, vol. 25, (1899), pp. 22.

[17] V. R. Prabhu and S. L. Dabral, "A status paper on Bamboo in Maharashtra State", 1989, Proc. Seminar on Silviculture and management of bamboos, held at institute of Deciduous Forests, Jabalpur (M.P), (1989) December 13-15, pp. 59-77.

[18] R. Prasad, "Effects of grazing closure on rehabilitation of flowered bamboos areas in Mandla forest in Madhya Pradesh", Journal of Tropical Forestry, vol. 1, no. II, (1985), pp. 145-151.

[19] R. Prasad and A. S. Parihar, "Rehabilitation and management of flowered bamboos in Mandla-Jabalpur forests of Madhya Pradesh", Journal of Tropical Forestry, vol. 10, (1994), pp. 1, 3-7.

[20] S. N. Rai and K. V. S. Chauhan, "Distribution and growing stock of bamboos in India", Indian Forester, vol. 124, no. 2, (1998), pp. 89-98.

[21] R. Gopal, "Natural regeneration of bamboo (Dendrocalamus strictus) after gregarious flowering and its effect on the forage and browse availability in Bandhavgarh National Park (M.P)", Proc.Seminar on Silviculture and management of bamboos, Institute of Deciduous Forests, Jabalpur (M.P), (1989) December 13-15, pp. 119.

[22] J. K. Rawat and D. C. Kahduri, "National Report on the status of Bamboos and Rattan in India", Submitted to, INBAR sponsored workshop on "Strategy 2005”Beijing (China), (1999) April 12-14.

[23] RFRI (Rain Forest Research Institute), Recommendations of Expert Consultation on "Strategies for sustainable utilization of bamboo resources subsequent to Gregarious Flowering in North-East", at RFRI, Jorhat (Assam), (2002) April 24-25.

[24] N. C. Shah, "Flowering of bamboos, Dendrocalamus hookeri and Dendrocalamus strictus in Assam and Bihar States", Indian Forester, vol. 94, (1968), pp. 717.

[25] H. N. Tatwawadi and B. G. Kali, "Gregarious flowering of bamboo Dendrocalamus strictus in Jarida range of East Melghat division", Amravati Circle - Maharashtra State.Indian Forester, vol. 109, no. 2, (1983), pp. 111-114.

[26] R. S. Troup, “The Silviculture of Indian Trees”, Oxford Publication, vol. 3, (1921), pp. 977-1013.

\section{Authors}

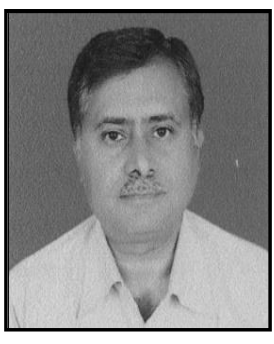

Dr. O. P. Chaubey, is working as Head of Forest Botany Branch in M.P. State Forest Research Institute, Jabalpur (M.P.) India. He was awarded in Ph.D. degree in Forest Ecology in 1986 from Dr. H.S. Gaur University, Sagar, (Madhya Pradesh, India). He has to his credit two books, 13 monograph of various forestry species and more than 75 research papers published in both National and International journals. He has 30 years of research experience in field of forestry. He has completed more than 22 externally funded research projects in the capacity of Principal Investigator. He has organized a number of symposia/ workshops at National and State levels. He has imparted trainings to field foresters, University scholars, NGOs and Rural Communities engaged in conservation and management of biological diversity. 


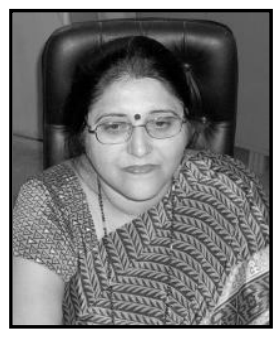

Dr. Archana Sharma, is working as Head of Seed Technology Branch in M.P. State Forest Research Institute, Jabalpur. She was awarded in Ph.D. degree in Seed Science in 1993 from Dr. H.S. Gaur University, Sagar, (Madhya Pradesh, India). She has to her credit more than 50 research paper published in both National and International journals, three bulletins and fourteen brochures. She has 20 years of research experience in seed technology. She has completed more than 15 externally funded research projects in the capacity of Principal Investigator. She has organized a number of trainings and workshops at National and State levels. She has imparted trainings to field foresters, University scholars, NGOs and Rural Communities engaged in seed technology, sustainable management and harvesting of bio resources.

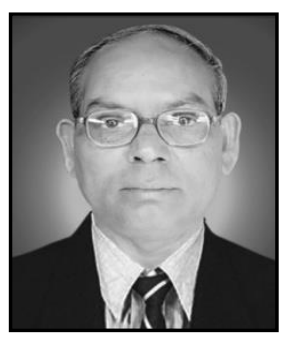

Dr. Ram Prakash, is an Indian Forest Service (IFS) Officer of 1981 batch, borne on Madhya Pradesh cadre. Besides working in various capabilities as field forester, he possesses long forestry research experience of about 20 years by serving as Additional Director and Director, State Forest Research Institute, Jabalpur (M.P.). He has worked in various fields of forestry research, like silviculture, management, extension, etc. He was awarded Ph.D. degree in Physics, by Agra University. He has to his credit a number of research reports, brochures and research papers published in various scientific journals. He has also conducted study tours to Norway. Currently he has been working as the director, State Forest Research Institute, Jabalpur since January 2012. 